\title{
Nitrogen Flow in a Recirculating Operation of Litopenaeus vannamei Maturation in Ecuador
}

\author{
Intriago $\mathrm{P}^{1 *}$, Espinoza $\mathrm{J}^{2}$, Cabrera $\mathrm{J}^{2}$, Sanchez $\mathrm{A}^{2}$ and Navarrete $\mathrm{A}^{2}$ \\ ${ }^{1}$ División Balanceados, Guayaquil- Ecuador, South Florida Farming Corp, USA \\ ${ }^{2}$ Empagran Semacua, Division Laboratorios, La Diablica-Anconcito-Santa Elena-Ecuador, USA
}

\begin{abstract}
The nitrogen flow together with dissolved nutrients and other parameters are described in a large shrimp maturation operation in Ecuador. In summary, only $8.9 \%$ of the nitrogen input ended in animal tissue. Nitrate-N and dissolved organic nitrogen (DON) accounted for more than $95 \%$ of the nitrogen pool. The nitrogen dynamics in the system is driven by a nitrification based trickling filter attached population and a free living heterotrophic carbon limited in the sump. The average nitrification rate of TAN (total ammonia nitrogen) averaged $44.81 \mathrm{gd}^{-1}$. The trickling filters worked as a nitrifier body and also reducing the organic load. There is also some evidence that the trickling filters might have also play some role in denitrification. Nitrate never reached high concentrations $\left(<3.7 \mathrm{mg} \mathrm{L}^{-1}\right.$ nitrate- $\left.\mathrm{N}\right)$, hence did not present a danger to the productivity of the system. In general either inorganic or organic phosphorous did not undergo any major change during the study. BOD values in the sump were low averaging $1.1 \mathrm{mg} \mathrm{L}^{-1} \mathrm{~d}^{-1} \mathrm{more} \mathrm{likely}$ as a result of the carbon limitation of the system. A combination of low $\mathrm{C}: \mathrm{N}$ ratio and high load of organic nitrogen in the trickling filter could be part of the key factors running this system. The semi closed recirculating system presented in this study has been used since 2004 providing a steady yield of nauplii without the seasonal effects typical of open system and without the accumulation of deleterious amount of waste nitrogen or the presence of pathogens. The present study demonstrates the feasibility of using a simple and inexpensive semi closed recirculating systems in a large commercial scale.
\end{abstract}

Keywords: Litopenaeus vannamei; Semi closed recirculating system; Maturation; Nitrification

Abbreviations: BOD: Biochemical Oxygen Demand; GSI: Gonadosomatic Index

\section{Introduction}

Penaeid culture practices have evolved from the simple systems described by Hudinaga [1] and Cook and Murphy [2] to high density floc and recirculating aquaculture systems (RAS) [3-7].

During the 70's, Mock and coworkers [8,9] were pioneers in describing and designing RAS for penaeid culture. At that time, this system may have been considered expensive and non-needed as there were few if any environmental regulations, major disease challenges or contamination issues which affect open systems. Since there, successful reproductive activity by Litopenaeus vannamei in completely closed systems have been reported $[10,11]$. These results demonstrated that closed systems can support reproductive performance at commercially acceptable levels.

Currently, RAS has become a priority, reasons for this; access to coastal areas; cost of land; runoff affecting water source, waste water regulations, and so on. In addition, because of their close nature of RAS, the risk of disease is also reduced. RAS typically include fish, shrimp or mollusk rearing tanks sustained by a water treatment process, which is focused on the detoxification of nitrogenous wastes, oxygenation, removal of suspended solids, and typically water exchange does not exceeds $10 \%[12,13]$.

Wastewater effluent from RAS comprises mainly feces, uneaten food and bacteria biomass, all of them rich in organic nutrients, minerals and vitamins. Heterotrophic bacteria are capable of taking up a variety of dissolved organic nitrogen (DON) compounds that may be sources of both nitrogen and carbon for biosynthesis or may also be used as sources of energy. Nutrients, released from the microbial activity include ammonia, nitrite and nitrate.
The accumulation of inorganic nitrogen and organic waste products in intensive aquaculture systems is one of the major limiting factors preventing further intensification. TAN (total ammonia nitrogen) and nitrite can be toxic to shrimp and accumulates not only through excretion of ammonia but also by the breakdown of organic solids. One important obstacle in RAS systems could be the accumulation of nitrate. High nitrate concentrations must be prevented as high concentration can affect shrimp. A detailed review of the nitrogen biogeochemistry and its process in aquaculture has been carried out by several researchers [14-20].

All the sea coastal countries around the world are aware of the need of increasing their knowledge of how the variations of oceanographic conditions influence the composition, distribution and abundance of the living resources of the sea [21,22]. These fluctuations have been documented in different topics. For instances, changes associated to the composition and abundance of the algae osmoprotectant dimethylsulfoniopropionate (DMSP), the primary productivity, penaeid shrimp larvae, groundfish species and the recruitment of fish stocks [23-27].

In this context, the Pacific Ocean off the coast of Ecuador is characterized by two differentiated seasonal periods; rainy summer (January to April) and a dry winter (July to October). In summer, a

*Corresponding author: Intriago P, División Balanceados, Guayaquil-Ecuador South Florida Farming Corp, USA, E-mail: sffarming@yahoo.com

Received August 11, 2012; Accepted October 18, 2012; Published October 25 2012

Citation: Intriago P, Espinoza J, Cabrera J, Sanchez A, Navarrete A (2012) Nitrogen Flow in a Recirculating Operation of Litopenaeus vannamei Maturation in Ecuador. J Aquacult Res Dev 3:153 doi:10.4172/2155-9546.1000153

Copyright: (C) 2012 Intriago P, et al. This is an open-access article distributed under the terms of the Creative Commons Attribution License, which permits unrestricted use, distribution, and reproduction in any medium, provided the original author and source are credited. 
southward coastal flow of warm low nutrient concentration and salinity water from the Panama Bight is dominant. Whereas, during the winter this mass of water is displaced north, in response to a strengthening of the trade winds and the richer, colder and higher salinity water mass of the Humboldt Current [21]. Additionally, the coast of Ecuador is also characterized by the periodical occurrence of "El Niño". During this, anomalously high temperatures are observed in the upper layer of the ocean. An equally important event is that of "La Niña" which is characterized mainly by sea temperatures that are below the mean value and also has repercussions on the distribution of both coastal and oceanic resources [28].

Along the coast of Ecuador, regardless of the type of fluctuation, oceanographic changes impact both nauplii and larvae production. For example, egg and nauplii production per female ranged from 200,000 and 110,000 respectively per female in the steady months, in contrast, these values sharply dropped (up to $40 \%$ ) during seasonal changes. Consequently, there was a need to evaluate a semi closed recirculating system to stabilize production. The present study describes the design, operation and the nitrogen dynamics of a semi closed recirculating system initiated in 2004 and has since enabled the continuous production of higher rates and more stable production for almost 8 years, with an annual production averaging of 12 billion nauplii and 1.2 billion post larvae.

\section{Materials and Methods}

\section{The maturation unit}

The maturation unit studied consist of 25 circular and 6 rectangular tanks (5.78 and $18.93 \mathrm{~m}^{3}$ of volume respectively, $258 \mathrm{~m}^{3}$ of water) holding a total of 3,190 broodstock of L. vannamei, 1,487 females (average weight $40.8 \mathrm{~g} \pm 4.02$ ) and 1,703 males, (with an average weight of $36.56 \mathrm{~g} \pm 2.0$ ). Animals were fed six equal doses a day at $2 \mathrm{am}, 9$ am, $11 \mathrm{am}, 1 \mathrm{pm}, 6 \mathrm{pm}$ and $11 \mathrm{pm}$ with $30 \mathrm{Kg}$ of fresh frozen food, which consist of $54.5 \%$ of a mix of squid, mussels and oysters, $22.7 \%$ of adult Artemia biomass, $13.6 \%$ of squid and $9.2 \%$ of bloodworms. Daily mortality was determined by picking out and registering dead animals once a day.

Growth rate and gonadosomatic index (GSI) was determined in marked animals. In order to avoid effects on mating, growth rate was determined in the non-matured population. GSI=gonad weight $\times 100$ Body Weight- 1 . The nitrogen retention was calculated using data from the non-matured population and including the GSI from the mating population, assuming that protein concentration of the ovaries was $18 \%$ [29]. Daily both eggs and nauplii were separately collected, rinsed using a $100 \mu \mathrm{m}$ nylon mesh, and distributing them into $6 \times 15$ Liters buckets. Total count was determined by calculating the average from 10 samples counts per bucket using $1 \mathrm{~mL}$ pipette. The semi closed recirculating systems consist of $95 \mathrm{MT}$ (metric ton) sump, with a side stream trickling filter, circulation pump ( $810 \mathrm{~L} \mathrm{~min}^{-1}$ Pacer Inc.), and the maturation tanks. The water returned to the sump by gravity flow (Figure 1A-C).

An average of $18.6 \%$ of the water from system (Figure 1A) was exchanged daily from 6:00 am to $3 \mathrm{pm}$ with fresh sea water to offset evaporation, siphoning, movement of animals, tank harvest or detoxifying the system. Every day $2 \mathrm{Kg}$ of sodium bicarbonate were dissolved into 20 Liters using water from the sump and added to the sump at dusk at a rate of 7 Liters per hour to compensate for any loss in alkalinity due to nitrification.

The trickling filter system consists of 8 circular fiber glass towers, each tower with 4 levels of dishes ( $160 \mathrm{~cm}$ of diameter $\times 10 \mathrm{~cm}$ of height).

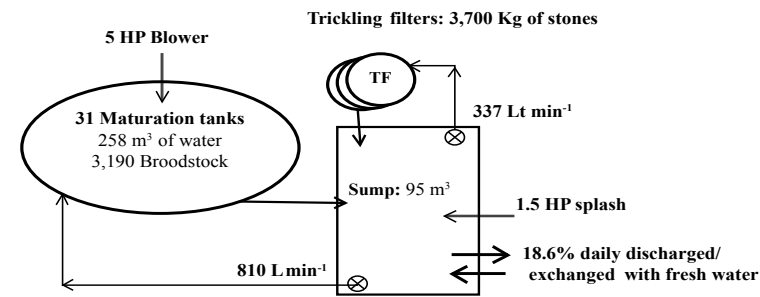

Figure 1a: Diagram of semi closed recirculating system used in Semacua.

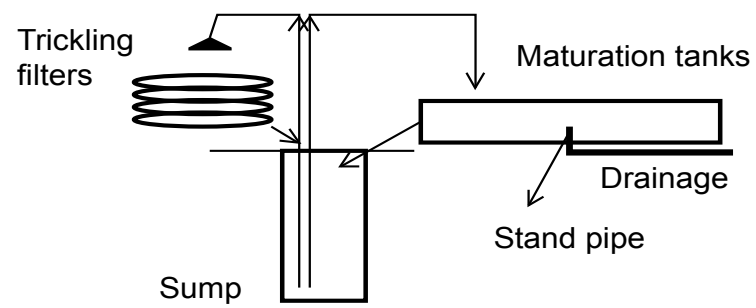

Figure 1b: Side view diagram of the semi closed recirculating system used in Semacua.

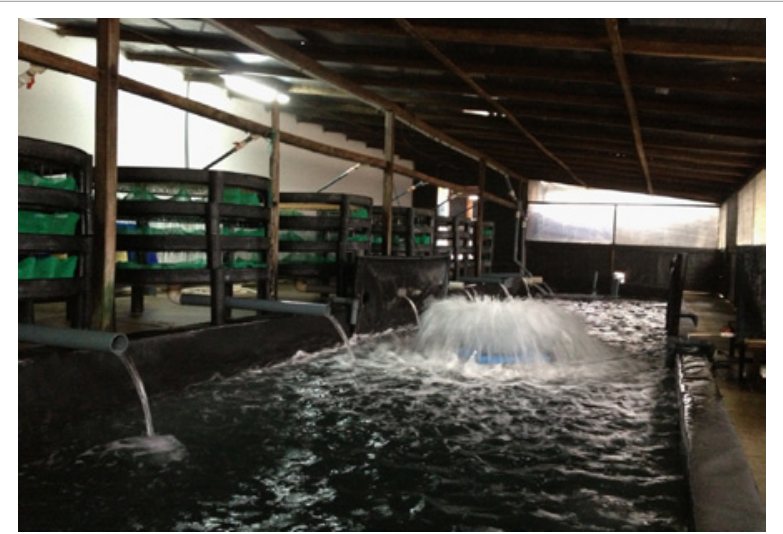

Figure 1c: Sump with trickling filters in the semi closed recirculating system used in Semacua.

All dishes are flat bottom with hundreds of small holes so water cascade down as shower from dish to dish. First level from every tower had no stones substrate media, but is the level in which the water sprinkles homogeneously to the lower levels. In the three lower levels, $154.2 \mathrm{~kg}$ of stones per level are evenly distributed along the surface of the dishes (average height $4 \mathrm{~cm}$ ), $3700 \mathrm{~kg}$ in total. The density and volume of the stones was calculated in $2.58 \mathrm{~g} \mathrm{~mL}^{-1}$ and $1.43 \mathrm{~m}^{3}$ respectively. Below the bottom dish of each tower, a funnel shaped bottom collect the treated water from the tower and flushes it back to the sump (Figure 1A-C). A $337 \mathrm{~L} \mathrm{~min}^{-1}$ Pacer pump, pulled water from the sump into the battery of trickling filters (Figure 1A-C), and then returned to the sump by gravity. For calculation purposes the water from the sump $\left(95 \mathrm{~m}^{3}\right)$ passed 5.1 times day ${ }^{-1}$ through the battery of trickling filters.

Aeration was provided in the sump by a $1.5 \mathrm{HP}$ splash Kasco Marine Inc., whereas the maturation tanks were aerated by a $10 \mathrm{HP}$ blower using air stones inside airlifts placed in each tank.

\section{Experiments A and B}

Nitrogen conversion analysis: The rationale of this experiment was to evaluate the trickling filter as a nitrification and filtration treatment 
unit and to find out differences produced by the organic load in the sump found during the day. Water samples for both nutrient and BOD (biochemical oxygen demand) were taken during 3 consecutive days at 6:45 am, 11:45 am and 4:45 pm. Water from the sump and at the exit of the trickling filters were pooled to improve homogenization using a 40 Liters carboy. This experiment was repeated twice (experiment $\mathrm{A}$ and $\mathrm{B}$ ) with the difference that we included BOD analysis only in experiment B. Logistics problems did not allow as to perform BOD analysis in experiment $\mathrm{A}$.

The volumetric TAN conversion rate (VTR) and Nitrite-N (VNR) conversion rate by the trickling filters were determined using Malone and Pfeiffer's formula [18].

$$
\begin{aligned}
& \operatorname{VTR}\left(\mathrm{g} \mathrm{N}^{3} \mathrm{~m}^{3}\right)=\left(\text { TANI}^{-T A N}{ }_{\mathrm{E}}\right) \times \mathrm{Qr} / \mathrm{Vb} \\
& \operatorname{VNR}\left(\mathrm{g} \mathrm{N}^{\mathrm{n}} \mathrm{m}^{3}\right)=\left(\text { Nitrite-NI-Nitrite- } \mathrm{N}_{\mathrm{E}}\right) \times \mathrm{Q}_{\mathrm{r}} / \mathrm{V}_{\mathrm{b}}
\end{aligned}
$$

Where $\mathrm{Q}_{\mathrm{r}}$ is the flow rate through the filter (m3d-1), $\mathrm{Vb}$ is the total volume of the media $\left(\mathrm{m}^{3}\right)$. TANI or Nitrite-NI represents the influent TAN or Nitrite- $\mathrm{N}$ concentration $\left(\mathrm{g} \mathrm{N} \mathrm{m}^{-3}\right)$, and TANE or Nitrite-NE represents the effluent TAN or Nitrite concentration $\left(\mathrm{g} \mathrm{N} \mathrm{m}^{-3}\right)$.

Chemical analysis: Hach reagents for total ammonia nitrogen, TAN (method 8155), nitrite nitrogen (method 8507), nitrate nitrogen (method 8192), TKN (method 8075, the term TKN, Total Kjeldahl Nitrogen refers to the combination of ammonia and organic nitrogen), orthophosphate (method 8048), and total phosphorus; TP (method 8190), were used.

The concentration of each nutrient was determined using a calibration curve in full strength sea water. All readings were recorded on a Hach DR 2000 spectrophotometer. Each value represents an average of four replicates. All samples were filtered through a nominal $0.7 \mu \mathrm{m}$ pore size, glass fiber filter (Whatman $4.25 \mathrm{~cm} \mathrm{GF/F} \mathrm{Springfield}$ Mill, UK), and hence they were considered as dissolved nutrients.

Several calibrations curves were made using full strength sea water. It was found that the traditional calibration curve approach produced more accurate results than using the recommended program on the spectrophotometer. All calibration was fitted with a blank as zero, table 1 shows the slope and statistics for each parameter analyzed. The percentage of recovery was over $90 \%$ in all the parameters except in $\mathrm{TP}$ that ranged $65 \%$.

Dissolved organic nitrogen (DON) and total nitrogen (TN) were calculated by the following formulas:

\section{DON=TKN-TAN.}

\section{$\mathrm{TN}=\mathrm{TKN}+$ Nitrite-N+Nitrate-N.}

The ratio N/P (representing Total inorganic nitrogen (TIN)/soluble reactive phosphate) and TN/TP (TN/TP) was determined as follow:

\section{$\mathrm{N} / \mathrm{P}=\mathrm{TIN} /$ orthophosphate-P}

\begin{tabular}{|l|l|l|l|l|l|}
\hline Parameter & N & Slope & SD & CV & $\begin{array}{l}\text { Reagents used } \\
\text { from HACH Method }\end{array}$ \\
\hline TAN & 4 & 0.569 & \pm 0.010 & $1.81 \%$ & 8155 \\
\hline Nitrite-N & 4 & 0.193 & \pm 0.007 & $3.7 \%$ & 8507 \\
\hline Nitrate-N & 9 & 1.996 & \pm 0.091 & $4.56 \%$ & 8192 \\
\hline TKN-N & 4 & 197.310 & \pm 3.868 & $1.96 \%$ & 8075 \\
\hline Orthophosphate-P & 4 & 0.666 & \pm 0.035 & $5.28 \%$ & 8048 \\
\hline TP-P & 4 & 2.036 & \pm 0.202 & $9.93 \%$ & 8190 \\
\hline
\end{tabular}

Table 1: This table summarizes value and statistics of each calibration curve (intercept was set as blank or zero) for all parameters analyzed. $\mathrm{N}$ represents the number of calibration curves carried out.

\section{$\mathrm{TN} / \mathrm{TP}=\mathrm{TON} / \mathrm{TP}$}

Nitrogen in the shrimp and fresh feed was determined by the Kjeldahl method. Dry weight or water content was determined by drying at $60^{\circ} \mathrm{C}$ for 2 days.

BOD analysis: BOD was analyzed using weighed corrected BOD bottles $(300 \mathrm{~mL})$, covered with aluminum foil and incubated in situ (sump) for 6 hours. Each value represents the average of 5 replicates including the control or time zero. $\mathrm{BOD}_{24 \mathrm{~h}}$ was determined by measuring the dissolved oxygen (DO) by the classical Winkler procedure [30]. Water for BOD was collected in a 40 Liters carboy (Nalgene) slightly aerated. BOD bottles were carefully filled using a rubber tube from the placed at the end of spigot which reach the bottom of the bottles taking care of non-producing air bubbles. The presence or nitrification activity, was carried out by using a nitrifier inhibitor (nitrifier inhibitor formula 2533 (Nitrapyrin) from Hach at $0.6 \mathrm{~g}^{\text {bottle }}{ }^{-1}$ ). Nitrapyrin [2-chloro6-(trichloromethyl)-pyridine] is the most widely used inhibitor of nitrification. It inhibits the first step of nitrification, the oxidation of ammonia to nitrite [31,32].

In order to eliminate any possible interference with nitrite, iron or any reducing or oxidizing compound, $4.5 \mathrm{gL}^{-1}$ of Sodium azide (Sigma, Co) was included in the Winkler solution [33]. After filling all BOD bottles, they were left for $30 \mathrm{~min}$ for acclimation before fixing time zero bottles and or placing the remaining bottles for incubation.

$$
\mathrm{BOD}_{24 \mathrm{~h}}=\frac{(\text { DO inntial })-(\mathrm{DO} \text { final }) \times 24}{\text { Incubation time }(\mathrm{h})}
$$

Carbon analysis: The effect of the ratio C:N was studied using 0 (control), 5 and $10 \mathrm{mgCL}^{-1}$. Water from the sump was placed in 200 Liters fiber glass container with aeration and the corresponding amount of carbon. The organic carbon used was citric acid. BOD was determined in time 0 and every 2 hours. All analysis was carried out using 4 replicates.

\section{Physic-chemical measurements}

Temperature, $\mathrm{pH}$, dissolve oxygen (DO) and shrimp culture parameters were measured daily in situ. Salinity was measured with a refractometer (Aquatic Ecosystems). Temperature and DO were measured with a Model 550A dissolved oxygen meter (YSI, Yellow Springs, $\mathrm{OH}$ ). The $\mathrm{pH}$ was recorded using an Oaklon $\mathrm{pH}$ 5/6 \& ion 5/6.

When compared data were analyzed by two-way ANOVA, significant differences between the treatments means were compared by LSD test. Differences were considered significant at an alpha level of 0.05 .

\section{Results}

The average temperature during the time of the experiment was $28.3^{\circ} \mathrm{C}$. The $\mathrm{pH}$ and oxygen in the sump were always slightly higher than at the drainage of the trickling filters (Table 2).

Protein and water content of both fresh feed and broodstock is presented in table 3. The maturation unit consists of a total population

\begin{tabular}{|l|l|l|l|}
\hline & Temp. oC & pH & O2 mg L$^{-1}$ \\
\hline Sump & $28.3 \pm 0.2$ & $7.7 \pm 0.0$ & $6.0 \pm 0.0$ \\
\hline Inlet TF & $28.3 \pm 0.2$ & $7.6 \pm 0.0$ & $5.9 \pm 0.3$ \\
\hline Outlet TF & $28.1 \pm 0.2$ & $7.5 \pm 0.0$ & $5.6 \pm 0.3$ \\
\hline
\end{tabular}

Table 2: Average daily values recorded of temperature ${ }^{\circ} \mathrm{C}, \mathrm{pH}$ and oxygen (mg L-1 and $\%$ of saturation) in the sump, inlet and outlet of the trickling filter (TF). 


\begin{tabular}{|c|c|c|c|}
\hline \multicolumn{2}{|c|}{ Fresh feed } & \multicolumn{2}{c|}{ Broodstock } \\
\hline$\% \mathrm{~N}$ & $\%$ water & $\% \mathrm{~N}$ & $\%$ water \\
\hline 1.54 & 84.41 & 3.10 & 72.98 \\
\hline \pm 0.12 & \pm 0.31 & \pm 0.10 & \pm 0.26 \\
\hline
\end{tabular}

Table 3: Nitrogen and water content of the frozen feed and Broodstock $( \pm$ one standard deviation). Average values are the result of 4 replicates, \pm one standard deviation.

\begin{tabular}{|c|c|c|}
\hline Feed utilization & Nitrogen (g) & $\%$ of $N$ \\
\hline Feed Input (FI) & 462 & 100 \\
\hline Waste ${ }^{a}$ & 420.9 & 91.1 \\
\hline Daily Weight Gain (DWG) & 41.1 & 8.9 \\
\hline
\end{tabular}

Table 4: Daily mass balance of dietary feed dry matter (DM) and Nitrogen (N), where: a waste is defined as the uneaten feed and all excretory compounds (feces and urine).
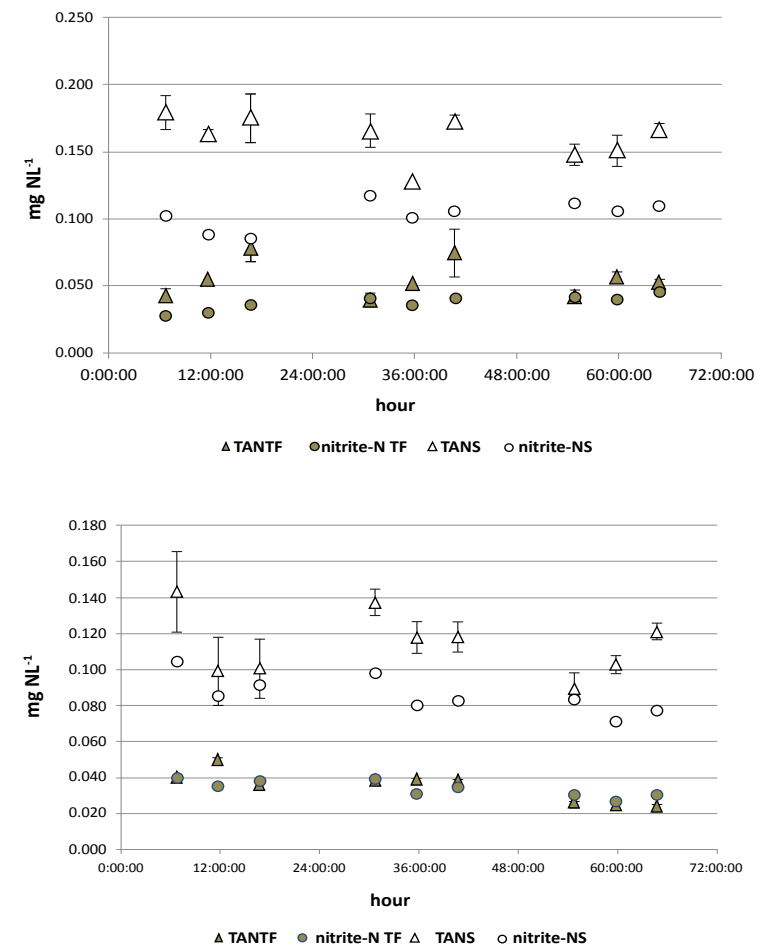

Figure 2: TAN and Nitrite-N readings in the sump (S) and after passing the trickling filter (TF) of the Experiments $\mathrm{A}$ (above) and $\mathrm{B}$ (below). The experiments were carried out during 3 consecutive days at 3 hours, 6:45, 11:45 and 16:45, and with a week difference. Average values are the result of 4 replicates, \pm one standard deviation.

of 3,190 broodstock with a total biomass of $123 \mathrm{Kg}$, equivalent to 3.81 $\mathrm{Kg}$ of N. Animals were fed daily with $30 \mathrm{Kg}$ of fresh frozen chopped marine mix which represents a load of $0.462 \mathrm{Kg}$ of $\mathrm{N} \mathrm{d}^{-1}$. Broodstock daily mortality was $0.3 \%$. The daily average mating rate was $18 \%$, averaging 250,000 and 175,000 eggs and nauplii per female respectively, equivalent to a $70 \%$ hatch rate. Average growth rate of non-mature female and male was 1.5 and $1.4 \mathrm{~g}^{\text {week }}{ }^{-1}$ respectively. GSI of mating population was $6.43 \pm 0.7 \%$. Daily nitrogen retention was calculated at $41.1 \mathrm{~g} \mathrm{~d}^{-1}$ which is equivalent to $8.9 \%$ of the total nitrogen load.

A deduced daily mass balance is presented in table 4 . This table presents the nitrogen retention $(8.9 \%)$ by broodstock and the waste, as the sum of non-eaten feed, and excretion.

Dissolved inorganic nutrients for experiments A and B are shown in tables 5 and 6 and figures 2 and 3. There is a clear reduction of both
TAN and nitrite- $\mathrm{N}(\mathrm{p}<0.05)$ after passing through the trickling filters (Figure 2). On the other hand, the concentration of nitrate-N did not match the reduction of both TAN and nitrite-N (Figure 3).

The concentration of orthophosphate-P was not affected by the filter treatment $(\mathrm{p}<0.05)$. It averaged from 0.436 in the experiment $A$ to $0.376 \mathrm{mg} \mathrm{PL}^{-1}$ in experiment $\mathrm{B}$ (Table 5). The average ratio for the ratio $\mathrm{N}$ :P was 7.1 for the drainage of the trickling filter to 8.5 in the sump. The dissolved organic nitrogen (DON) and total phosphorus (TP) were more abundant during experiment $\mathrm{A}$ than $\mathrm{B}$. DON as percentage of the total nitrogen (TN) ranged from 31.1 to $39.7 \%$ in the sump to 37.3 to $43.4 \%$ in the discharge of the trickling filter, respectively (Table 6). The volumetric TAN conversion rate (VTR) and Nitrite-N (VNR) conversion rate were $28.6 \mathrm{~g} \mathrm{~N} \mathrm{~m}^{-3}$ and $19.9 \mathrm{~g} \mathrm{~N} \mathrm{~m}^{-3}$ respectively.

BOD analysis revealed a drop between sump and trickling filter. There was no difference between $(\mathrm{p}<0.05)$ samples from the sump incubated with and without the inhibitor Nitrapyrin, in contrast samples taken from the drainage of the trickling filter showed a large variation of results (Table 4).

\section{Discussion}

Reports of nitrogen retention in shrimp culture ranges from 23 to $55 \%$ and varied with culture condition and species [20,34-37]. Most of the work published has been carried out using dry feed in pond or raceways culture. One exception was the work published by Wickins [38]. Wickins fed fresh feed to Penaeus monodon in RAS, and calculated that approximately $80 \%$ of the nitrogen of the daily ration
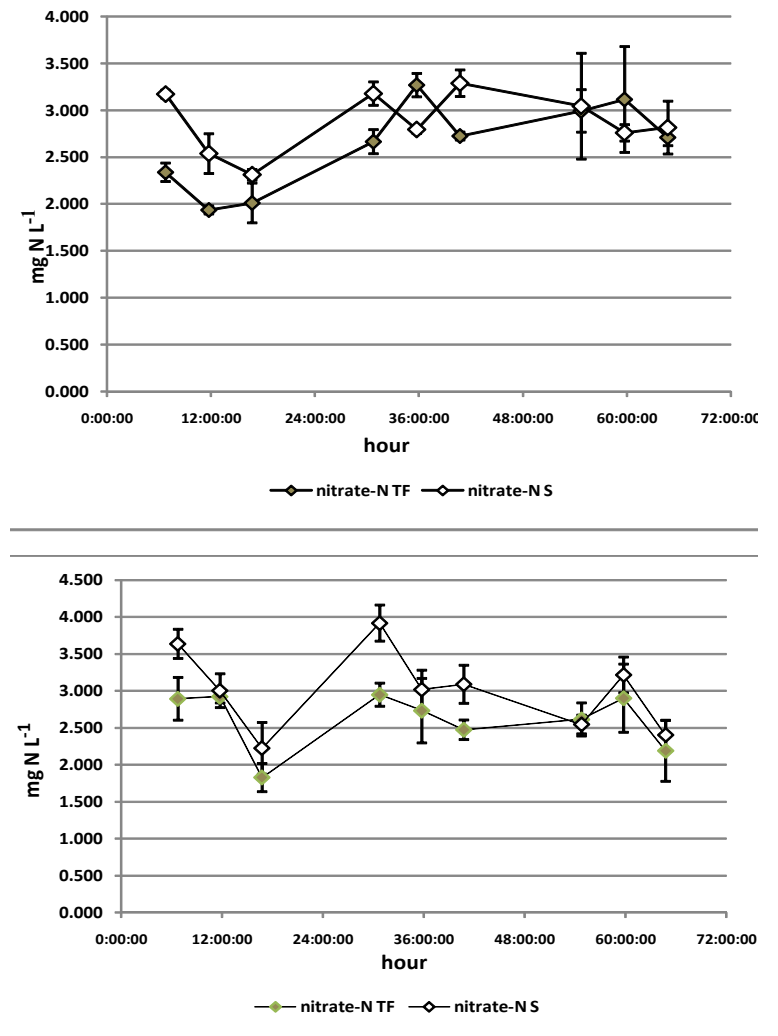

Figure 3: Nitrate- $\mathrm{N}$ readings in the sump (S) and after passing the trickling filter (TF) of the Experiments $A$ (above) and $B$ (below). The experiments were carried out during 3 consecutive days at 3 hours, 6:45, 11:45 and 16:45, and with a week difference. Average values are the result of 4 replicates, \pm one standard deviation. 


\section{BOD vs Carbon addition}

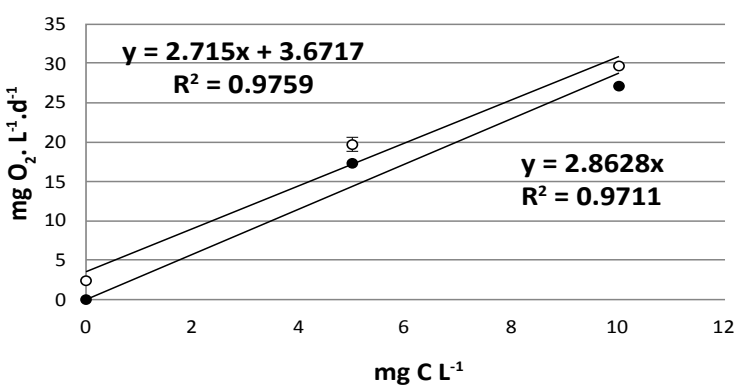

Figure 4: Relationship between BOD and organic carbon. Open circles are actual measured values. In order to determine the concentration of $\mathrm{O}_{2}$ needed to oxidize $1 \mathrm{mg}$ of carbon, closed circles representing zeroed control were included. Each point represents the average of 4 replicates \pm one standard deviation.

was not converted into prawn flesh and ended as load on the filters. In the present study only $8.9 \%$ of the nitrogen load ended as animal tissue. Shrimp maturation requires fresh frozen feed, and to achieve a good maturation, broodstock demands to be fed ad libitum or in excess. Calculating the amount of the wasted feed is extremely hard, but it would not be wrong to suggest that most of the waste $(91.9 \%)$ were uneaten feed, and it can be partly attributed to the nibbling habit of crustaceans $[39,40]$.

It is known that all aquatic crustaceans are strictly ammonotelic [41], and the rate of excretion is related to salinity [42], as well as size, concentration of TAN, molt stage, feed intake, temperature, salinity, $\mathrm{pH}$ and dissolved oxygen [43]. By assuming an excretion rate of $13.11 \mu \mathrm{g}$. $\mathrm{TANgh}^{-1}[38,43,44]$, and considering that TAN represents $70 \%$ of the nitrogen excreted, the total nitrogen and TAN excretion nitrogen rate for this study would be 55.3 and $39.7 \mathrm{~g} \mathrm{~N} \mathrm{~d}^{-1}$ respectively [43]. Thus, the total nitrogen excretion would represent $12 \%$ of the total nitrogen load (462 $\mathrm{g} \mathrm{N} \mathrm{d}^{-1}$ ), resulting that uneaten feed and feces represent $79.9 \%$ of the nitrogen load, a percentage close to reported by Wickins [38].

Both TAN and Nitrite- $\mathrm{N}$ were rapidly nitrified in the trickling filters (Table 5 and Figure 2), interestingly, the Nitrate- $\mathrm{N}$ fraction did not increase accordingly to expectations (Table 5 and Figure 3). Nitrate- $\mathrm{N}$ concentration was kept almost similar with a slightly tendency to decrease after passing through the trickling filters (Figure 3 ). It is tempting to suggest that concentration of Nitrate- $\mathrm{N}$ was the product of nitrification and in a small degree denitrification within the trickling filters (Table 5).

The trickling filter is a biofilm fed by a diffusion controlled process driven by concentration gradient across the film; both physical and chemical conditions influence the filter performance $[17,45]$. A decrease in oxygen to below suboptimal levels from the external boundary to within the biofilm is not uncommon. An increase in organic or TAN loading will cause more consumption of oxygen [46]. Schramm and coworkers working in a trickling filter of an eel water recirculation system found that nitrification was restricted to a narrow zone of 50 microns on the very top of the film [47]. Similarly to the hyporheic zone, trickling filters will create a variety of microniches, promoting the activity of some otherwise poor competitors, such as chemolithotrophers, especially if low dissolved carbon is present. A variety of anaerobic respiratory pathways, such as nitrate, ferric ion, sulphate and even methanogenic respiration will be employed even in aerobic sediments [48]. Figure 3 shows an almost constant drop of Nitrate- $\mathrm{N}$ at the drainage of the trickling filter, more likely as result of low oxygen to anaerobic pockets in the trickling filter. These pockets could be the result of the constant organic load; its development will depend on both, the amount of organic load and transit time. In this connection, BOD from water passed through the trickling filters was lower than water from the sump (Table 6), demonstrating the filtration capabilities of the trickling filters and hence the drop of oxygen and $\mathrm{pH}$ shown in table 2 .

Both Nitrate-N and DON accounted for about $95 \%$ of the dissolved nitrogen pool in the system. It is obvious that the concentration of both is the result of bioaccumulation.

The lack of effect of the nitrifying inhibitor in water taken from the sump, suggest that there are two different processes occurring in

\begin{tabular}{|c|c|c|c|c|c|c|c|c|}
\hline Exper. A & \multicolumn{2}{|l|}{ TAN } & \multicolumn{2}{|c|}{ Nitrite-N } & \multicolumn{2}{|c|}{ Nitrate-N } & \multicolumn{2}{|c|}{$\begin{array}{l}\text { orthophosphate- } \\
\text { P }\end{array}$} \\
\hline \multicolumn{9}{|c|}{ Trickling filters } \\
\hline Time & av & \pm & av & \pm & av & \pm & av & \pm \\
\hline 6:45:00 & 0.043 & 0.005 & 0.028 & 0.000 & 2.338 & 0.0 & 0.40 & 0 \\
\hline 11:45:00 & 0.055 & 001 & 30 & 0.0 & 93 & & & \\
\hline $16: 4$ & 0.078 & & 36 & & & & & \\
\hline 30:45:00 & 0.040 & 004 & 041 & 0.001 & 2.664 & & & \\
\hline 35:45:00 & 0.052 & 003 & .036 & 0.002 & 3.267 & 125 & 405 & \\
\hline 40:45:00 & 0.075 & 018 & .040 & 0.000 & 2.724 & 043 & .437 & 3 \\
\hline 54:45:00 & 0.042 & 0.004 & 0.042 & 0.001 & 2.992 & 227 & 48 & 0 \\
\hline :45:00 & 0.05 & 04 & 0.0 & & & & & \\
\hline 64:45:00 & 0.052 & 02 & & & & & & \\
\hline average & .055 & 006 & .038 & 0.001 & 2.63 & & & \\
\hline dev & 0.014 & 005 & 006 & 0.001 & 0.46 & 161 & . & 006 \\
\hline \multicolumn{9}{|c|}{ Sump } \\
\hline 45:00 & 0.179 & 0.012 & 0.102 & 0.000 & 3.171 & .04 & .46 & 0.002 \\
\hline 11:45:00 & 0.16 & & $0 . c$ & 0 & & & & \\
\hline 16:45:00 & 0.175 & 019 & 0.085 & $0.0 c$ & & & & \\
\hline 30:45:00 & 0.165 & 012 & 0.117 & 0.001 & 177 & 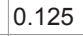 & & 01 \\
\hline 35:45:00 & 0.127 & 0.003 & 0.101 & 0.002 & 794 & fu & & .003 \\
\hline 40:45:00 & 0.172 & 005 & 0.1 & 0. & 287 & & & \\
\hline 4:45:00 & $0.14 \varepsilon$ & 008 & 0.1 & 0.0 & 04 & & & 1 \\
\hline 59:45:00 & 0.15 & 011 & 0.10 & 0.00 & 75 & 0 & & \\
\hline 00 & 0 & & c & 0.003 & 81 & & & \\
\hline \multicolumn{9}{|c|}{ rickling filters } \\
\hline erage & 0.161 & 009 & 0.103 & 0.001 & 2.877 & 3 & 8 & .006 \\
\hline stde & 0.01 & & 0.0 & & & & & \\
\hline $6: 45: 00$ & 0.04 & 003 & 0.04 & 0.000 & 2. & 28 & & 3 \\
\hline 11:45:00 & 0.050 & 0.008 & 0.03 & 0. & 2.9 & c & & \\
\hline 16:45:00 & 0.036 & 02 & 0.0 & $0.0 c$ & 1.8 & 2 & & 3 \\
\hline 30:45:00 & 0.039 & 05 & 0.039 & 0.001 & 2.9 & 86 & & 06 \\
\hline 35:45:00 & 0.039 & 007 & 0.031 & 0.000 & 2.734 & 37 & 10 & 00 \\
\hline 40:45:00 & 0.038 & & 0.03 & 0 & 2.4 & & & \\
\hline$: 45: 00$ & 0.02 & 007 & 0.03 & & 2. & & & \\
\hline 45:00 & 0.024 & 0 & 0.0 & $0.0 c$ & 2.9 & & & 0 \\
\hline 64:45:00 & 0.024 & 0.006 & 0.030 & 0.0 & 2.190 & & & 12 \\
\hline average & 0.035 & 0.005 & 0.034 & 0.001 & 2.612 & 266 & 378 & .006 \\
\hline stdev & 0.009 & 0.002 & 0.005 & 0.000 & 0.388 & 141 & 0.032 & 0.003 \\
\hline \multicolumn{9}{|c|}{ Sump } \\
\hline & & & & 0.001 & 3. & & & 0.020 \\
\hline & 0.09 & & & & & & & \\
\hline 16:45:00 & 0.100 & 0.009 & 0.091 & 0.001 & 2.224 & 127 & 337 & .003 \\
\hline 30:45:00 & 0.137 & 0.019 & 0.098 & 0.001 & 3.919 & 0.229 & 0.419 & 0.00 \\
\hline 35:45:00 & 0.118 & 0.009 & 0.080 & 0.001 & 3.019 & 0.263 & 0.364 & 0.004 \\
\hline
\end{tabular}

Table 5: Dissolved inorganic nutrients recorded in Experiment $A$ (above) and $B$ (below). All data expressed as $\mathrm{mg} \mathrm{L}^{-1}$. Average values are the result of 4 replicates, \pm one standard deviation. 


\begin{tabular}{|c|c|c|c|c|c|c|c|c|c|}
\hline \multirow[t]{2}{*}{ Exp. A } & \multicolumn{2}{|l|}{ TKN-N } & DON & \multirow{2}{*}{\multicolumn{3}{|c|}{\begin{tabular}{|l|r} 
TN & TP \\
Trickling filters
\end{tabular}}} & \multicolumn{3}{|l|}{ TN/TP } \\
\hline & & & & & & & & & \\
\hline Time & av & \pm & av & \pm & av & \pm & av & & \\
\hline $6: 45$ & 2.269 & 0.977 & 2.226 & 4.634 & 0.416 & 0.004 & 11.131 & & \\
\hline $11: 45$ & 2.466 & 0.140 & 2.412 & 4.433 & 0.426 & 0.006 & 10.417 & & \\
\hline $16: 45$ & 3.453 & 0.698 & 3.375 & 5.499 & 0.454 & 0.012 & 12.112 & & \\
\hline $6: 45$ & 2.269 & 0.419 & 2.229 & 4.974 & 0.461 & 0.004 & 5 & & \\
\hline $11: 45$ & 1.677 & 0.698 & 1.625 & 4.981 & 0.454 & 0.012 & 10.970 & & \\
\hline $16: 45$ & 2.466 & 0.698 & 2.392 & 5.231 & 0.462 & 0.020 & 11.318 & & \\
\hline $6: 45$ & 1.677 & 0.140 & 1.635 & 4.711 & 0.527 & 0.003 & 8.934 & & \\
\hline $11: 45$ & 1.283 & 0.419 & 1.226 & 4.436 & 0.450 & 0.003 & 9.859 & & \\
\hline $16: 45$ & 1.776 & 1.116 & 1.724 & 4.530 & 0.485 & 0.003 & 9.34 & & \\
\hline average & 2.149 & 0.589 & 0.589 & 4.825 & 0.459 & 0.007 & 10.542 & & \\
\hline stdev & 0.639 & 0.340 & 0.631 & 0.372 & 0.032 & 0.006 & 1.00 & & \\
\hline & & & & Su & $\mathrm{mp}$ & & & & \\
\hline $6: 45$ & 2.960 & 0.140 & 2.781 & 6.233 & 0.520 & 0.006 & 11.982 & & \\
\hline $11: 45$ & 1.579 & 0.698 & 1.416 & 4.203 & 0.422 & 0.012 & 9.949 & & \\
\hline $16: 45$ & 2.368 & 1.395 & 2.193 & 4.763 & 432 & 0.013 & 11. & & \\
\hline $6: 45$ & 2.171 & 0.419 & 2.023 & 5.324 & 0.499 & 0.003 & 10.674 & & \\
\hline $11: 45$ & 1.184 & 1.116 & 1.033 & 4.048 & 0.458 & 0.003 & 8.83 & & \\
\hline $16: 45$ & 2.368 & 1.116 & 2.202 & 5.292 & 0.462 & 0.009 & 11.4 & & \\
\hline average & 2.236 & 0.791 & 2.076 & 5.216 & 0.471 & 0.009 & 11.051 & & \\
\hline stdev & 0.560 & 0.382 & 0.559 & 0.736 & 0.034 & 0.005 & 1.134 & & \\
\hline & & & & Trick & 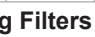 & & & & \\
\hline Exper. B & TKN-N & DON & TN & & $T p$ & & TN/TP & BOD & \\
\hline Time & av & \pm & av & \pm & av & \pm & av & \pm & av \\
\hline $6: 45$ & 2.171 & .395 & 2.131 & 5.105 & 0.479 & 0.011 & 10.658 & 0.556 & 0.468 \\
\hline 11:45 & 0.839 & 0.519 & 0.789 & 3.798 & 0.357 & .009 & 10.628 & 0.973 & 0.543 \\
\hline $16: 45$ & 1.924 & 0.691 & 1.888 & 3.790 & 0.438 & 0.003 & 8.648 & 0.703 & 0.592 \\
\hline $6: 45$ & 1.677 & 0.613 & 1.651 & 4.322 & 0.420 & 0.011 & 10.280 & 0.541 & 0.325 \\
\hline 11:45 & 1.924 & 0.567 & 1.900 & 4.853 & 0.415 & 0.010 & 11.699 & 0.717 & 0.116 \\
\hline $16: 45$ & 1.924 & 0.888 & 1.900 & 4.144 & 0.392 & 0.013 & 10.561 & 1.231 & 0.454 \\
\hline average & 1.628 & 0.591 & 1.593 & 4.274 & 0.417 & 0.009 & 10.289 & 0.896 & 0.392 \\
\hline stdev & 0.479 & 0.149 & 0.484 & 0.543 & 0.039 & 0.004 & 1.257 & 0.269 & 0.150 \\
\hline $6: 45$ & 1.332 & 0.296 & 1.189 & 5.074 & 0.474 & 0.007 & 10.697 & 1.311 & 0.476 \\
\hline 11:45 & 0.789 & 0.426 & 0.690 & 3.878 & 0.358 & 0.004 & 10.822 & 1.437 & 0.459 \\
\hline $16: 45$ & 2.318 & 0.672 & 2.218 & & 0.417 & 0.013 & & 1.434 & 305 \\
\hline $6: 45$ & 2.417 & 0.652 & 2.328 & 5.047 & 0.411 & 0.004 & 12.287 & 1.556 & 0.362 \\
\hline 11:45 & 1.332 & 0.589 & 1.214 & 4.431 & 0.377 & 0.003 & 11.747 & 1.145 & 0.490 \\
\hline $16: 45$ & 1.283 & 0.342 & 1.165 & 4.456 & 0.396 & 0.013 & 11.253 & 1.280 & 0.221 \\
\hline $6: 45$ & 2.417 & 0.652 & 2.328 & 5.047 & 0.411 & 0.004 & 12.287 & 1.556 & 0.362 \\
\hline $11: 45$ & 1.381 & 0.426 & 1.279 & 4.670 & 0.423 & 0.011 & 11.040 & 0.875 & 0.408 \\
\hline $16: 45$ & 1.727 & 0.888 & 1.606 & 4.207 & 0.382 & 0.005 & & 1.304 & .768 \\
\hline average & 1.557 & 0.575 & 1.442 & 4.649 & 0.411 & 0.007 & 11.300 & 1.304 & 0.341 \\
\hline stdev & 0.520 & 0.220 & 0.527 & 0.481 & 0.039 & 0.004 & 0.518 & 0.199 & 0.12 \\
\hline
\end{tabular}

Table 6: Dissolved organic nutrients N/P ratio and BOD recorded in Experiment $A$ (above) and $\mathrm{B}$ (below). All data expressed as $\mathrm{mg} \mathrm{L}^{-1}$ or $\mathrm{mg} \mathrm{L}^{-1} \mathrm{~d}^{-1}$ in BOD. Average values are the result of 4 replicates, \pm one standard deviation.

our recirculation system. On one hand, the trickling filter with a major nitrifying activity and a heterotrophic counterpart present in both the sump and rearing tanks.

As general rule, an estimated of the TAN generated per day in an aquaculture-heterotrophic production can be calculated using the following equation:

$P_{\text {TAN }}=$ F $\times$ PC $\times 0.144$; where $P_{\text {TAN }}$ is the production rate of TAN (Kg/ day); $\mathrm{F}$ is the feed rate and $\mathrm{PC}$ the protein concentration of the feed (decimal value) [16]. The application of this equation in the study would result in a daily production of $66.5 \mathrm{~g}$ of TAN, than divided by the total volume of the system would represent about $0.18 \mathrm{mg} \mathrm{TAN} \mathrm{L}^{-1}$, concentration similar to found in the system in the present study.
The C:N ratio of the substrates will determine whether or not bacteria take up inorganic nitrogen or will regenerate nitrogen during the mineralization [49-51]. Under the correct conditions bacteria can take up dissolved inorganic nitrogen while simultaneously liberating $\mathrm{NH}_{4}$ in decomposition [52]. Thus, bacteria can be competing for $\mathrm{NH}_{4}$, regenerating $\mathrm{NH}_{4}$, or both. Feeding the system with only high protein diets will result in a low $\mathrm{C}: \mathrm{N}$ ratio. The $\mathrm{C}: \mathrm{N}$ ratio of a mean atomic formula of protein, $\mathrm{C}_{138} \mathrm{H}_{217} \mathrm{O}_{45} \mathrm{~N}_{39} \mathrm{~S}$, is 3.5, this ratio would approach to 4 when considering the fat and carbohydrate content of the fresh feed [53]. In addition, the present study experimentally showed the carbon limitation of the system by measuring the effect of carbon addition on BOD. The oxygen:carbon ratio was 2.86 (Figure 4), very close to the stoichiometric 2.66 found when glucose is oxidized to water and $\mathrm{CO}_{2}$.

In RAS, fecal bacteria not only inoculate the system but also contribute to its abundance, productivity and process [54]. Interestingly the same authors found an increase in the protein concentration in the feces due partly to bacteria external colonization, a process than eventually will benefit the shrimp through coprophagy [55,56]. Neither the concentration or composition of bacteria was not determined in the present study, however it is unequivocally clear than the semi closed recirculating system described in this study is driven by an attached nitrifiers population restricted to the trickling filters and a general free living or attached heterotrophic population mainly thriving in the sump.

Several problems have been identified and are in process to be studied. It is clear that RAS or closed systems could be reservoirs of pathogenic microorganisms for animal and humans [57], hence horizontal and vertical transmission. There is also a potential accumulation of metabolites, hormones, heavy metals which could impair the rearing embryonic and larval development [58]. A further reduction of water exchange to lower to $10 \%$ daily is under study, though the increase in turbidity is an obstacle to face. Turbidity increases the manual work; hence increase stress, hamper the capture of ripped or inseminated females, or generally observing the health of the animals.

The present study shows a simple and inexpensive semi closed recirculating system, running at low $\mathrm{C}: \mathrm{N}$ ratio, efficient enough to control the concentration of harmful nitrogen. A combination of low $\mathrm{C}: \mathrm{N}$ ratio and high load of organic nitrogen in the trickling filter could be part of the key factors running this system. This system has supplied to our hatchery an average of 1 billion nauplii per month for the last 8 years. This same concept has been applied with same success in several operations in maturation in other countries in the region.

\section{References}

1. Hudinaga M, Kaigi GK (1942) Reproduction development and rearing of Penaeus japonicus Bate. Japanese Journal of Zoology 10: 305-393.

2. Cook HL, Murphy MA (1966) Rearing penaeid shrimp from egg to postlarvae. Proceedings of the Conf. Southeast Assoc. Game Comm 19:283-288.

3. Davis DA, Arnold CR (1998) The design, management and production of recirculating raceway system for the production of marine shrimp. Aquaculture Engineering 17: 193-211

4. Menavesta P, Panritdam T, Sihanonth P, Powtongsook S, Chuntapa B, et al (2001) Design and function of a closed, recirculating seawater system with denitrification for the culture of black tiger shrimp broodstock. Aquaculture Engineering 25: 35-49.

5. Burford MA, Thompson PJ, McIntosh RP, Bauman RH, Pearson DC (2003) Nutrient and microbial dynamics in high-intensity, zero-exchange shrimp ponds in Belize. Aquaculture 219: 393-411.

6. Otoshi CA, Arce SM, Moss SM (2003) Growth and reproductive performance 
of broodstock shrimp reared in a biosecure recirculating aquaculture system versus a flow-through pond. Aquaculture Engineering 29: 93-107.

7. Burford MA, Thompson PJ, McIntosh RP, Bauman RH, Pearson DC (2004) The contribution of flocculated material to shrimp (Litopenaeus vannamei) nutrition in a high-intensity, zero-exchange system. Aquaculture 232: 525-537.

8. Mock CR, Neal RA, Salser BR (1973) A closed raceway for the culture of shrimp. Proceedings of the World Mariculture Society 4: 247-259.

9. Mock CR, Ross LR, Salser BR (1977) Design and preliminary evaluation of a closed system for shrimp culture. Proceedings of the World Mariculture Society 8: 335-369.

10. Chen F, Reid B, Arnold CR (1991) Maturing, spawning, and egg collecting of the white shrimp Penaeus vannamei Boone in a recirculating system. J Wor Aquacul Society 22: 167-172.

11. Lotz JM, Ogle J T (1994) Reproductive Performance of the White-Legged Shrimp Penaeus vannamei in Recirculating Seawater Systems. J World Aquaculture Society 25: 477-482.

12. Masser MP, Rakocy J, Losordo TM (1999) Recirculating aquaculture tank production systems: Management of recirculating systems. Southern Regional Aquaculture Center Pub SRAC-452.

13. Brazil BL (2006) Performance and operation of a rotating biological contactor in a tilapia recirculating aquaculture system. Aquaculture Engineering 34: 261 274

14. Hagopian DS, Riley JG (1998) A closer look at the bacteriology of nitrification Aquaculture Engineering 18: 223-244.

15. Hargraves JA (1998) Nitrogen biogeochemistry of aquaculture ponds Aquaculture 166: 181-212.

16. Ebeling JM, Timmons MB, Bisogni JJ (2006) Stoichiometry of photoautotrophic, autotrophic, heterotrophic bacterial control of ammonia-nitrogen in zeroexchange production systems. Aquaculture 257: 346-358.

17. Eding EH, Kamstra A, Verreth JAJ, Huisman EA, Klapwijk A (2006) Design and operation of nitrifying trickling filters in recirculating aquaculture: A review. Aquaculture Engineering 34: 234-260.

18. Malone RF, Pfeiffer TJ (2006) Rating fixed film nitrifying biofilters used in recirculating aquaculture systems. Aquaculture Engineering 34: 389-402.

19. Van Rijn J, Tal Y, Schreier HJ (2006) Denitrification in recirculating systems: Theory and applications. Aquaculture Engineering 34: 364-376.

20. Holl CM, Glazer CT, Moss SM (2011) Nitrogen stable isotopes in recirculating aquaculture for super-intensive shrimp production: Tracing the effects of water filtration on microbial nitrogen cycling. Aquaculture 311:146-154.

21. Cucalon E (1989) Oceanographic characteristics off the coast of Ecuador In: Olsen S, Arriaga L, (eds) A Sustainable Shrimp Mariculture Industry for Ecuador. Narragansett, RI. Coast; Resources Center, University of Rhode Island, USA, pp 185-194.

22. Karl DM (1999) A Sea of Change: Biogeochemical Variability in the North Pacific Subtropical Gyre. Ecosystems 2: 181-214.

23. Zimmerman RJ, Minello TJ (1989) Recruitment and distribution of postlarval and early juvenile penaeid shrimp in a large mangrove estuary in the Gulf of Guayaquil during 1985. In: Olsen S, Arriaga L (Eds) A Sustainable Shrimp Mariculture Industry for Ecuador. International Coastal Resources Management Project, Technical Report Series TR-E-6, University of Rhode Island, Rhode Island, pp: 233-243.

24. Berresheim H, Andreae M O, Iverson R L, Li SM (1991) Seasonal variations of dimethylsulfide emissions and atmospheric sulfur and nitrogen species over the western North Atlantic Ocean. Tellus B 43: 353-372.

25. Yoch DC (2002) Dimethylsulfoniopropionate: Its Sources, Role in the Marine Food Web, and Biological Degradation to Dimethylsulfide. Appl Environ Microbiol 68: 5804-5815.

26. Chai F, Jiang M, Barber RT, Dugdale RC, Chao Y (2003) Interdecadal Variation of the Transition Zone Chlorophyll Front: A Physical-Biological Model Simulation between 1960 and 1990. J Oceanography 59: 461-475.

27. Somarakis S, Ramfos A, Palialexis A, Valavanis VD (2011) Contrasting multispecies patterns in larval fish production trace inter-annual variability in oceanographic conditions over the N.E. Aegean Sea continental shelf (Eastern Mediterranean). Hydrobiologia 670: 275-287.
28. Cruz M, Gabor N, Mora E, Jiménez R, Mair J (2003) The known and unknown about marine biodiversity in Ecuador (continental and Insular). Gayana 67 232-260.

29. Nisa K, Sultana R (2010) Variation in the Proximate Composition of Shrimp Fenneropenaeus penicillatus at Different Stages of Maturity. Pak J Biochem Mol Biol 43:135-139

30. Parsons TR, Maita Y, Lalli CM (1984) A manual of Chemical and Biologica Methods for seawater analysis. Pergamon Press, New York, USA

31. Belser LW, Schmidt EL (1981) Inhibitory Effect of Nitrapyrin on Three Genera of Ammonia-Oxidizing Nitrifiers. Applied and Environmental Microbiology 41 819-821.

32. Matsuba D, Takazaki H, Sato Y, Takahashi R, Tokuyama T, et al. (2003) Susceptibility of Ammonia-Oxidizing Bacteria to Nitrification Inhibitors. Z Naturforsch C 58: 282-287.

33. Broenkow WW, Cline JD (1969) Colorimetric determination of dissolved oxygen at low concentrations. Limnology and Oceanography 14: 450-454

34. Briggs MRP, Fvnge- Smith SJ (1994) A nutrient budget of some intensive marine shrimp ponds in Thailand. Aquaculture Research 25: 789-811.

35. Avnimelech Y, Ritvo G (2003) Shrimp and fish pond soils: processes and management. Aquaculture 220: 549-567.

36. Thakur DP, Lin CK (2003) Water quality and nutrient budget in closed shrimp (Penaeus monodon) culture systems. Aquaculture Engineering 27: 159-176.

37. Audelo -Naranjo JM, Martinez- Córdova LR, Voltolina D (2010) Nitrogen budget in intensive cultures of Litopenaeus vannamei in mesocosms, with zero water exchange and artificial substrates. Rev Biol Mar Oceanogr 45: 519-524.

38. Wickins JF (1985) Ammonia production and oxidation during the culture of marine prawns and lobsters in laboratory recirculation systems. Aquaculture Engineering 4: 155-174.

39. Bordner C E, Conklin D E (1981) Food consumption and growth of juvenile lobsters. Aquaculture 24: $285-300$.

40. FAO (2005) Cultured Aquatic Species Information Programme. Penaeus monodon. Cultured Aquatic Species Information Programme. Text by Kongkeo, H. In: FAO Fisheries and Aquaculture Department. Rome.

41. Regnault M (1987) Nitrogen excretion in marine and freshwater Crustacea. Biological Reviews 62: 1-24.

42. Weihrauch D, Wilkie MP, Walsh PJ (2009) Ammonia and urea transporters in gills of fish and aquatic crustaceans. J Exp Biol 212: 1716-1730.

43. Jiang D, Lawrence AL, Neill WH, Gong H (2000) Effects of temperature and salinity on nitrogenous excretion by Litopenaeus vannamei juveniles. J Exp Mar Biol Eco 253: 193-209.

44. Burford MA, Williams KC (2001) The fate of nitrogenous waste from shrimp feeding. Aquaculture 198: 79-93.

45. Chen S, Ling J, Blancheton JP (2006) Nitrification kinetics of biofilm as affected by water quality factors. Aquaculture Engineerig 34: 179-197.

46. Zhang TC, Fu YC, Bishop PL (1995) Competition for substrate and space in biofilms. Water Environmental Research 67: 992-1003.

47. Schramm A, Larsen LH, Revsbech NP, Ramsing NB, Amann R, et al. (1996) Structure and function of a nitrifying biofilm as determined by in situ hybridization and the use of microelectrodes. Appl Environ Microbiol 62: 4641-4647.

48. Storey RG, Fulthorpe RR, Williams DD (1999) Perspectives and predictions on the microbial ecology of the hyporheic zone. Freshwater Biology 41: 119-130.

49. Jorgensen NOG, Kroer N, Coffin RB (1994) Utilization of Dissolved Nitrogen by Heterotrophic Bacterioplankton: Effect of Substrate C/N Ratio. Appl Environ Microbiol 60: 4124-4133.

50. Goldman J C, Dennett MR (2000) Growth of marine bacteria in batch and continuous culture under carbon and nitrogen limitation. Limnol Oceanogr 45 789-800.

51. Kirchman D L (2000) Uptake and regeneration of inorganic nutrients by marine heterotrophic bacteria. p. 261-288. In D. L. Kirchman (ed.), Microbial ecology of the oceans. Wiley- Liss, New York.

52. Tupas LM, Koike I, Karl DM, Holm-hansen O (1994) Nitrogen metabolism by 
Citation: Intriago P, Espinoza J, Cabrera J, Sanchez A, Navarrete A (2012) Nitrogen Flow in a Recirculating Operation of Litopenaeus vannamei Maturation in Ecuador. J Aquacult Res Dev 3:153 doi:10.4172/2155-9546.1000153

Page 8 of 8

heterotrophic bacterial assemblages in Antarctic coastal waters. Polar Biol 14:195-204

53. Fraga F (2001) Phytoplanktonic biomass synthesis: application to deviations from Redfield stoichiometry. Scientia Marina 65: 153-169.

54. Beardsley C, Moss S, Malfatti F, Azam F (2011) Quantitative role of shrimp fecal bacteria in organic matter fluxes in a recirculating shrimp aquaculture system. FEMS Microbiol Ecol 77: 134-145.

55. Johannes R E, Satomi M (1966) Composition and nutritive value of fecal pellets of a marine crustacean. Limnol Oceanogr 11: 191-197.
56. Frankenberg D, Smith Jr KL (1967) Coprophagy in marine Animals. Limnol Oceanogr 12: 443-450.

57. Pullela S, Fernandes CF, Flick GJ, Libey GS, Smith SA, et al. (1998) Indicative and pathogenic microbiological quality of aquacultured finfish grown in different production systems. J Food Prot 61: 205-210.

58. Martins CIM, Pistrim MG, Ende SSW, Eding EH, Verreth JAJ (2009) The accumulation of substances in Recirculating Aquaculture systems (RAS) affects embryonic and larval development in common carp Cyprinos carpio. Aquaculture 91: 65-73. 